\title{
Vitamin D gene polymorphisms and risk of acute cardiovascular events
}

\author{
Henrik Fox $^{\mathrm{a}, \mathrm{b}, *}$, Florian H. Seeger ${ }^{\mathrm{c}}$, Quirine Freiin von Quernheim ${ }^{\mathrm{d}}$, Elizabeth Ramos-Lopez ${ }^{\mathrm{d}}$ \\ ${ }^{a}$ Clinic for Thoracic and Cardiovascular Surgery, Herz- und Diabeteszentrum NRW, Ruhr-Universität Bochum, Bad Oeynhausen, Germany \\ ${ }^{\mathrm{b}}$ Heart Failure Department, Herz- und Diabeteszentrum NRW, Ruhr-Universität Bochum, Bad Oeynhausen, Germany \\ ${ }^{c}$ Department of Internal Medicine III, Division of Cardiology, Johann Wolfgang Goethe-University, Frankfurt am Main, Germany \\ ${ }^{\mathrm{d}}$ Department of Internal Medicine I, Division of Endocrinology, Diabetes and Metabolism of the Johann Wolfgang Goethe-University, Frankfurt am Main, Germany
}

\section{A R T I C L E IN F O}

\section{Keywords:}

Acute coronary syndrome

Cardiovascular disease

Gene polymorphisms

Vitamin D

\begin{abstract}
A B S T R A C T
Background: Low vitamin D levels have been associated with various diseases, including cardiovascular disease, although data are not consistent. Serum vitamin D levels depend on different synthesis steps which are controlled by gene cascade. This study investigated whether low serum levels of vitamin D and single nucleotide polymorphisms (SNPs) in genes involved in the vitamin D cascade (VDR, CYP2R1, CYP27B1, CYP24 and DBP) could be risk factors for acute coronary syndrome (ACS).

Materials and methods: 71 Patients with ACS and 443 healthy controls were genotyped for polymorphisms in genes of the vitamin D cascade. Clinical findings were correlated with serum levels of the vitamin D metabolites $1,25(\mathrm{OH})_{2} \mathrm{D}_{3}$ and $25(\mathrm{OH}) \mathrm{D}_{3}$.

Results: $25(\mathrm{OH}) \mathrm{D}_{3}$ and $1,25(\mathrm{OH})_{2} \mathrm{D}_{3}$ insufficiency was more common in ACS patients than in controls ( $\mathrm{p}<0.05$ ). After adjustments for variables and propensity score the SNPs rs4646536 and rs2296241 within CYP24 and CYP27B1 are significantly associated with ACS (p < 0.05). CYP27B1 rs4646536 genotype TT is more frequently found in ACS patients compared to healthy controls, whereas genotype TC is found at higher frequency in controls (79\% vs 44\% and 42\% vs 5\%, respectively, p < 0.01). CYP24 rs2296241 SNP genotype GG occurred less frequently in ACS vs controls (7\% vs 18\%), while genotype AG was found more frequently in ACS (79\% vs 57\%, p < 0.01).

Conclusions: Lower vitamin D levels as well as polymorphisms within the CYP27B1 and CYP24 genes seem to promote ACS. These findings may offer potential for identification of patients at increased risk for cardiovascular incidents.
\end{abstract}

\section{Introduction}

Vitamin D exists in two main forms, vitamin D2 (ergocalciferol) and vitamin D3 (cholecalciferol). Vitamin D2 is predominantly obtained from eukaryote sources, like fungi and yeast, whereas vitamin D3 is produced from 7-dehydroxycholesterol upon exposure to ultraviolet B radiation ${ }^{1}$ First, 7-dehydrocholesterol is converted into pre-vitamin D3 then a thermo-sensitive process isomerises pre-vitamin D3 to vitamin D3 that is delivered into the circulation where it binds to vitamin D binding protein (DBP) for systemic transport and delivery to target organs. In the liver, vitamin D3 is sequentially hydroxylated by cytochrome P450 enzymes, via 25-hydroyxlase (CYP2R1) among others, into 25-hydroxyvitamin D (25(OH)D; calcidiol or calcifediol), the major storage and circulating form of vitamin $\mathrm{D}^{2} ; 25(\mathrm{OH}) \mathrm{D}$ is frequently measured as an index of vitamin D status. Subsequently, a second hydroxyl group is added by $1 \alpha$-hydroxylase (CYP27B1) to convert 25(OH)D into the active metabolite 1,25-dihydroxyvitamin D $\left(1,25(\mathrm{OH})_{2} \mathrm{D}_{3}\right.$; calcitriol) in the kidney. ${ }^{3} 1,25(\mathrm{OH})_{2} \mathrm{D}_{3}$ binds to the nuclear vitamin D receptor (VDR) in target organs and forms a heterodimer complex with the retinoid $\mathrm{X}$ receptor (RXR), recruiting other transcriptional cofactors to regulate target gene transcription by interacting with vitamin D response elements (VDRE) in gene promoter regions. A decisive step in the metabolic process is degradation of $25(\mathrm{OH})$ $\mathrm{D}$ and $1,25(\mathrm{OH})_{2} \mathrm{D}_{3}$ by 24-hydroxylase (CYP24A1) ${ }^{4}$

There is a growing body of evidence to suggest that gene polymorphisms within the vitamin D cascade (DBP, CYP2R1, CYP27B1, CYP24 and VDR) may play an important role in the risk of developing a variety of autoimmune and non-autoimmune disease ${ }^{5}$ by modulating the vitamin D serum levels. ${ }^{6}$ In addition, epidemiological studies have linked low serum levels of $25-(\mathrm{OH}) \mathrm{D}$, with a range of medical

\footnotetext{
${ }^{*}$ Corresponding author. Heart Failure Department, Herz- und Diabeteszentrum NRW, Ruhr-Universität Bochum, Georgstr. 11, D-32545, Bad Oeynhausen, Germany.

E-mail address: akleemeyer@hdz-nrw.de (H. Fox).
} 
conditions, including cardiovascular diseases. ${ }^{7-12}$ In particular, low levels of vitamin $\mathrm{D}$ have been associated with acute myocardial infarction (MI). ${ }^{13,14}$ There even is evidence that lower vitamin D levels are linked to increased mortality. ${ }^{15}$ Although the role of $25(\mathrm{OH}) \mathrm{D}$ is controversial $^{16}$, several large prospective studies have demonstrated that higher levels of $25(\mathrm{OH}) \mathrm{D}$ are associated with a lower risk of cardiovascular morbidity and mortality compared with low 25(OH)D status. $^{8,17-21}$ There appears to be an inverse correlation between low serum levels of 25(OH)D and atherosclerotic calcification, which is an important cardiovascular risk factor. ${ }^{22-24}$ Data suggests that 25(OH)D has an important effect in cardiomyocytes, vascular smooth muscle cells and the vascular endothelium. ${ }^{25}$

Daily vitamin D supplementation has been shown to improve some cardiovascular risk markers in healthy overweight and obese subjects. ${ }^{26}$ However, the mechanisms by which vitamin D and its metabolites may influence the development of cardiovascular diseases, including MI, are not fully understood yet. It has been postulated that 25(OH)D and/or $1,25(\mathrm{OH})_{2} \mathrm{D}_{3}$ could act directly via VDRs in cardiac smooth muscle cells in the vessels or muscle of the heart, or indirectly by promoting calcium absorption in the gut. ${ }^{27}$

Nevertheless, at present the role of vitamin D in cardiovascular diseases remains unclear. ${ }^{28}$ Thus, studies failed to find an association between vitamin $\mathrm{D}$ and a reduction in mortality due to cardiovascular risk $^{29}$ or blood pressure ${ }^{30}$ or they found only a modest association. ${ }^{11}$

Given the controversial role of vitamin D in the pathogenesis of cardiovascular diseases, this study investigated whether low serum levels of vitamin $\mathrm{D}$ and polymorphisms in the vitamin D cascade (VDR, CYP2R1, CYP27B1, CYP24 and DBP) could be risk factors for acute coronary syndrome (ACS).

\section{Materials and methods}

\subsection{Study design}

This single center prospective surveillance study was conducted at the University Hospital of Frankfurt am Main between 2010 and 2012. The study protocol was approved by local ethics committee of Frankfurt University Hospital, Frankfurt am Main. All participants gave written informed consent prior to enrollment into the trial, which was conducted in accordance to the Declaration of Helsinki.

\subsection{Participants}

All patients who attended the Department of Cardiology (cardiology ward or intensive care unit) at the University Hospital of Frankfurt am Main were eligible for enrollment into the study. Inclusion criteria were ACS, as defined by the ESC/ACCF/AHA/WHF Third Universal Definition $^{31}$ and no vitamin D supplementation. There was no randomization or balanced selection for age, gender, race, region, medication or co-morbidities. A control group comprising volunteer blood donors without a history of coronary artery disease who were not receiving supplementary vitamin D was also included. Medical records, including diagnostic and therapeutic procedures, were obtained for all enrolled ACS patients.

\subsection{Genotyping}

Genomic DNA was obtained from whole blood within the first $6 \mathrm{~h}$ of hospital admittance and extracted using the salting-out procedure as previously described ${ }^{32}$ and amplified using polymerase chain reaction (PCR), restriction fragment length polymorphism (RFLP) or real time polymerase chain reaction (PCR-real time) methods for detection of single nucleotide polymorphisms (SNPs) within DBP (rs4588, rs7041), CYP2R1 (rs10741657, rs12794714), CYP24 (rs927650, rs2248137, rs2296241), CYP27B1 (rs10877012, rs4646536) and VDR (rs7975232, rs731236, rs1544410, rs10735810) genes, as previously described.
Table 1A

Baseline characteristics of the ACS study group ( $n=71)$.

\begin{tabular}{|c|c|}
\hline Age (years) & $64 \pm 13$ \\
\hline Male & $55(75 \%)$ \\
\hline BMI (body mass index) $\mathrm{kg} / \mathrm{m}^{2}$ & $27 \pm 5$ \\
\hline STEMI & 39 \\
\hline NSTEMI & 32 \\
\hline Left ventricular ejection fraction (\%) & $44 \pm 14$ \\
\hline Cardiac arrest & $5(7 \%)$ \\
\hline Cardiogenic shock & $14(20 \%)$ \\
\hline Prior history of myocardial infarction & $16(23 \%)$ \\
\hline NYHA functional class & $3 \pm 1$ \\
\hline Smoking & $35(49 \%)$ \\
\hline Smoking (pack years) & $35 \pm 18$ \\
\hline Chronic kidney disease & $23(32 \%)$ \\
\hline Chronic kidney disease (CKD stadium) & $3 \pm 1$ \\
\hline Dialysis & $3(4 \%)$ \\
\hline Cholesterol (mg/dl) & $174 \pm 41$ \\
\hline Triglycerides (mg/dl) & $132 \pm 70$ \\
\hline $\mathrm{HDL}(\mathrm{mg} / \mathrm{dl})$ & $43 \pm 14$ \\
\hline LDL (mg/dl) & $105 \pm 35$ \\
\hline HDL/LDL & $3 \pm 7$ \\
\hline Leucocytes $(/ \mathrm{nl})$ & $10 \pm 4$ \\
\hline HbA1c (\%Hemoglobin) & $6 \pm 1$ \\
\hline NT-pro-BNP (pg/ml) & $3711 \pm 6588$ \\
\hline Troponin (ng/ml) & $2441 \pm 3377$ \\
\hline Creatinine $(\mathrm{mg} / \mathrm{dl})$ & $1 \pm 1$ \\
\hline BUN (mg/dl) & $46 \pm 29$ \\
\hline PAD (peripheral artery disease) & $11(16 \%)$ \\
\hline CAD (coronary artery disease) & $71(100 \%)$ \\
\hline Coronary 1 vessel disease & $21(30 \%)$ \\
\hline Coronary 2 vessel disease & $18(25 \%)$ \\
\hline Coronary 3 vessel disease & $32(45 \%)$ \\
\hline Atrial fibrillation & $8(11 \%)$ \\
\hline Ventricular tachycardia & $3(4 \%)$ \\
\hline Stroke & $5(7 \%)$ \\
\hline Death & $5(7 \%)$ \\
\hline Arterial hypertension & $64(92 \%)$ \\
\hline Hyperlipidemia & $38(54 \%)$ \\
\hline Diabetes & $18(25 \%)$ \\
\hline Insulin dependent diabetes & $10(14 \%)$ \\
\hline Family history for cardiovascular disease & $19(27 \%)$ \\
\hline ASS & $71(100 \%)$ \\
\hline Clopidogrel & $34(48 \%)$ \\
\hline Prasugrel & $36(51 \%)$ \\
\hline Betablocker & $68(96 \%)$ \\
\hline ACE inhibitor & $63(89 \%)$ \\
\hline ATRB & $6(9 \%)$ \\
\hline Hydrochlorothiazide & $67(94 \%)$ \\
\hline Digitalis & $13(18 \%)$ \\
\hline Amiodarone & $5(7 \%)$ \\
\hline Spironolactone & $4(6 \%)$ \\
\hline Eplerenone & $11(16 \%)$ \\
\hline Statin & $68(96 \%)$ \\
\hline
\end{tabular}

Table 1B

Baseline characteristics of the healthy volunteers group $(n=443)$.

\begin{tabular}{lc}
\hline Age (years) & $35 \pm 15$ \\
\hline Male & $193(44 \%)$ \\
\hline
\end{tabular}

(Table 4) ${ }^{33-37}$ To confirm the accuracy of the methods, random samples of the studied polymorphisms were genotyped twice, and showed a concordance of $98 \%$.

\subsection{Measurement of $25(\mathrm{OH}) \mathrm{D}$ and $1,25(\mathrm{OH})_{2} \mathrm{D}_{3}$}

Plasma levels of $25(\mathrm{OH}) \mathrm{D}$ and $1,25(\mathrm{OH})_{2} \mathrm{D}_{3}$ were measured by radioimmunoassay (DiaSorin, Stillwater, Minnesota, USA and IDS, Frankfurt am Main, Germany, respectively). Levels of 25(OH)D were defined as insufficient if they were $<20 \mathrm{ng} / \mathrm{mL}$ (or $<50 \mathrm{nmol} / \mathrm{L})^{38}$. 
Table 2

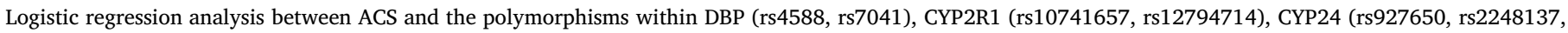

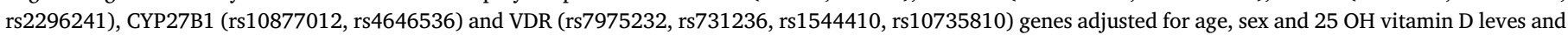
adjustments for propensity score.

\begin{tabular}{|c|c|c|c|c|c|c|c|}
\hline Gene & SNPs & Odds Ratio & Std. Err & $(95 \% \mathrm{CI})$ & $\begin{array}{l}\text { unadjusted } \\
\mathrm{p} \text { value }\end{array}$ & $\mathrm{p}$ value adjusted for age, sex, $25 \mathrm{OH}$ Vit D & $\mathrm{p}$ value adjusted for propensity score \\
\hline \multirow[t]{2}{*}{ DBP } & rs4588 & 1.42 & 0.58 & $0.64-3.17$ & 0.51 & 0.17 & 0.31 \\
\hline & rs7041 & 1.41 & 0.53 & $0.68-2.94$ & 0.50 & 0.15 & 0.13 \\
\hline \multirow[t]{2}{*}{ CYP2R1 } & rs10741657 & 1.83 & 0.63 & $0.94-3.58$ & 0.17 & 0.32 & 0.55 \\
\hline & rs12794714 & 1.38 & 0.48 & $0.69-2.74$ & 0.11 & 0.77 & 0.68 \\
\hline \multirow[t]{3}{*}{ CYP24 } & rs927650 & 0.84 & 0.31 & $0.41-1.72$ & 0.86 & 0.22 & 0.25 \\
\hline & rs2248137 & 0.87 & 0.32 & $0.42-1.79$ & 0.45 & 0.72 & 0.52 \\
\hline & rs2296241 & 0.53 & 0.24 & $0.21-1.30$ & $<0.001$ & $<0.001$ & 0.02 \\
\hline \multirow[t]{2}{*}{ CYP27B1 } & rs10877012 & 3.76 & 1.86 & $1.42-9.99$ & $<0.001$ & 0.57 & 0.77 \\
\hline & rs4646536 & 1.77 & 0.80 & $0.75-4.20$ & $<0.001$ & $<0.001$ & $<0.001$ \\
\hline \multirow[t]{4}{*}{ VDR } & rs7975232 & 1.41 & 0.59 & $0.62-3.19$ & 0.02 & 0.30 & 0.35 \\
\hline & rs731236 & 0.98 & 0.36 & $0.48-2.02$ & 0.69 & 0.39 & 0.35 \\
\hline & rs1544410 & 0.59 & 0.21 & $0.30-1.18$ & 0.07 & 0.96 & 0.93 \\
\hline & rs10735810 & 1.14 & 0.35 & $0.62-2.09$ & 0.97 & 0.33 & 0.42 \\
\hline
\end{tabular}

Table 3A

Distribution of the rs2296241 polymorphism within the CYP24 and rs4646536 within the CYP27B1 in patents with ACS and healthy controls.

\begin{tabular}{|c|c|c|c|c|c|}
\hline & \multicolumn{3}{|c|}{ CYP24 rs2296241 } & \multicolumn{2}{|c|}{ CYP27B1 rs4646536 } \\
\hline & Controls & ACS & & Controls & ACS \\
\hline & n (\%) & n (\%) & & n (\%) & n (\%) \\
\hline AG & $249(56.5)$ & $58(81.3)$ & TC & $191(43.3)$ & $56(78.7)$ \\
\hline AA & $114(25.8)$ & $7(9.9)$ & $\mathrm{CC}$ & $61(13.9)$ & $9(12.4)$ \\
\hline \multirow[t]{2}{*}{ GG } & $78(17.7)$ & $6(8.8)$ & TT & 189 (42.7) & $6(9.0)$ \\
\hline & $\mathrm{p}<0.01$ & & & $\mathrm{p}<0.01$ & \\
\hline
\end{tabular}

\section{Table 3B}

$25(\mathrm{OH})_{2} \mathrm{D}$ serum levels were still lower in the ACS patients. Therefore the $\mathrm{p}$ value reflects more the already insufficiency than a true influence of the polymorphism on the vitamin D levels. Vitamin levels are given as mean values.

\begin{tabular}{|c|c|c|c|c|c|}
\hline & \multicolumn{3}{|c|}{ CYP24 rs2296241 } & \multicolumn{2}{|c|}{ CYP27B1 rs4646536 } \\
\hline & Controls & ACS & & Controls & ACS \\
\hline & \multicolumn{5}{|c|}{$25(\mathrm{OH}) \mathrm{D}(\mathrm{ng} / \mathrm{mL})$} \\
\hline AG & 18.6 & 16.0 & TC & 17.7 & 16.9 \\
\hline AA & 19.1 & 17.6 & $\mathrm{CC}$ & 15.8 & 14.5 \\
\hline GG & $\begin{array}{l}16.0 \\
p=0.144\end{array}$ & 17.0 & TT & $\begin{array}{l}19.5 \\
p=0.142\end{array}$ & 13.2 \\
\hline
\end{tabular}

Plasma concentrations of $1,25(\mathrm{OH})_{2} \mathrm{D}_{3}$ were considered to be in the normal range if they were $20-25 \mathrm{pg} / \mathrm{mL}$, according to the manufacturer's instructions.

\subsection{Statistics}

Deviations from Hardy-Weinberg equilibrium, differences in genotype and allele distributions between groups were evaluated by Chisquared $\left(\chi^{2}\right)$ test (BiAS software, package 9.08; Epsilon, Weinheim, Germany). Continuous variables were compared by analysis of variance (ANOVA). Categorical comparisons were made using Chi-squared analysis. Propensity score and regression on propensity score analysis were calculated as previously reported. ${ }^{39,40}$ Statistical significance was defined as a p-value of $<0.05$. Statistical analyses were performed using SPSS for Mac OS X version 21.0 and using The R Project for Statistical Computing.

\section{Results}

\subsection{Patient characteristics}

Of 514 patients screened, 71 (55 male [75\%]) had ACS and were enrolled in the study (Table 1A). All participants were Caucasians. Mean patient age was 64 years for males and 68 years for females. Patients were divided into two groups: those with an acute ST elevation MI ( $\mathrm{n}=39 ; 29$ male [74\%]) and those with an acute non-ST elevation MI ( $\mathrm{n}=32 ; 24$ male [75\%]). Five patients (7\%) experienced cardiac arrest and underwent successful cardiopulmonary resuscitation, 14 patients (20\%) were in cardiogenic shock, and 16 patients (23\%) had a history of prior MI. A total of 443 healthy controls (244 male [55\%]) were included (Table 1B).

\subsection{Genotype analysis}

All samples were in Hardy-Weinberg equilibrium $(\mathrm{p}>0.05$ ) for each polymorphism. Thirteen different polymorphisms for the genes encoding DBP, CYP2R1, CYP27B1, CYP24A1 and VDR were studied.

After adjustments for variables and adjustments for propensity score the SNPs rs4646536 and rs2296241 within CYP24 and CYP27B1 genes are significantly associated with ACS ( $p<0.05$, Table 2). In this regard in CYP27B1 rs4646536 genotype TT is more frequently found in patients with ACS compared to healthy controls, whereas genotype TC is found at higher frequency in controls compared to ACS patients $(79 \%$ vs $44 \%$ and $42 \%$ vs $5 \%$, respectively, $p<0.01$ ), see Table $3 A$ and B. In addition to that CYP24 rs2296241 SNP genotype GG occurred less frequently in ACS patients vs controls ( $7 \%$ vs $18 \%$ ), while genotype AG was found more frequently in ACS $(79 \%$ vs $57 \%$, p $<0.01)$.

There were no significant differences between ACS patients and controls for any polymorphisms in genes encoding DBP, CYP2R1 or VDR genes. There was also no significant difference in these genes when patients were stratified according to gender and age (data not shown). Due to the small sample size, haplotype analysis was not performed.

\subsection{Plasma levels of $25(\mathrm{OH}) \mathrm{D}$ and $1,25(\mathrm{OH})_{2} \mathrm{D}_{3}$}

25(OH)D insufficiency $(<20 \mathrm{ng} / \mathrm{mL})$ was found in $81 \%$ of ACS patients compared with $28.6 \%$ of controls (Fig. $1 \mathrm{~A}$ and B). When measured within $6 \mathrm{~h}$ of diagnosis, ACS patients had significantly lower 25(OH)D levels than controls (13.2 vs $21.3 \mathrm{ng} / \mathrm{mL}, \mathrm{p}<0.05)$.

Low levels of $1,25(\mathrm{OH})_{2} \mathrm{D}_{3}(<20 \mathrm{pg} / \mathrm{mL})$ were found in $78 \%$ of ACS patients and $14 \%$ of controls, and patients had significantly lower plasma levels compared with controls ( 21.5 vs $16.1 \mathrm{pg} / \mathrm{mL}, \mathrm{p}<0.05$ ). Interestingly, patients carrying the genotype GG of the rs2248137 
Table 4

Genotyping conditions.

\begin{tabular}{|c|c|c|c|c|c|}
\hline Gen & SNP & Primers & PCR $(T \circ C)$ & Enzymes $^{\mathrm{a}}$ & References \\
\hline \multirow[t]{2}{*}{ DBP } & rs4588 & 5‘GAT CTC GAA GAG GCA TGT TTC 3’ & 58.8 & Styl & \\
\hline & rs4071 & 5‘GTT GCC TGT GTT CAC AGA CTC 3’ & & HaeIII & \\
\hline \multirow[t]{4}{*}{ CYP2R1 } & rs10741657 & 5'-GGGAAGAGCAATGACATGGA-3' & 61 & MnI & \\
\hline & & 5'-GCCCTGGAAGACTCATTTTG-3' & & & \\
\hline & rs12794714 & 5'-GCCATAAGTCCAACCAGGAA-3' & 63 & FokI & \\
\hline & & 5'-GGAAGCTTTGGAGAGCTGAA-3' & & & \\
\hline \multirow[t]{2}{*}{ CYP24 } & rs927650 & 5'-TGGTTGCATAACACA AACCTA-3' & 59 & BgII & \\
\hline & & 5'-CTGAAAGCCAGTAACAATGGT-3' & & & \\
\hline \multirow[t]{6}{*}{ VDR } & rs7975232 & 5'-AGTAAGAGTCTGGCAAAGATAGC-3' & 58 & ApaI & \\
\hline & rs731236 & 5'-AAACACTTCGAGCACAAGG-3' & & TaqI & \\
\hline & rs1544410 & 5'-GGCAACCTGAAGGGAGACGTA-3' & 60 & BsmI & \\
\hline & & 5'-CTCTTTGGACCTCATCACCGAC-3' & & & \\
\hline & rs10735810 & 5'-AGCTGGCCCTGGCACTGACTCTGCTCT-3' & 60 & FokI & \\
\hline & & $5^{\prime}$-ATGGAAACACCTTGCTTCTTCTCССТC-3‘ & & & \\
\hline \multicolumn{6}{|c|}{ Real-Time-PCR ${ }^{\mathrm{b}}$} \\
\hline \multirow[t]{2}{*}{ CYP24 } & rs2248137 & C_1915659 & & & \\
\hline & rs2296241 & C_1915656_30 & & & \\
\hline \multirow[t]{4}{*}{ CYP27B1 } & rs10877012 & forward: GGGAGTAAGGAGCAGAGAGGTAAA & & & \\
\hline & & reverse, AACAGAGAGAGGGCCTGTCT & & & \\
\hline & & FAM-labelled probe for $\mathrm{C}$ allele, TGTGGGAGA & & & \\
\hline & & VIC-labelled probe for A allele, CTGTGGGAGA & & & \\
\hline
\end{tabular}

The digestion products were separated on $3 \%$ agarose gel visualized by ethidiumbromide staining.

a All enzymes used for the RFLP analyses were purchased from New England Biolabs, Inc., Beverly, MA, USA and used according manufacturer's instructions.

b Real-Time PCR was analyzed using TaqMan assays in an ABI 7300 PCR (picture not shown) system under the conditions recommended by the manufacturer (Applied Biosystems).

polymorphism within the CYP24 gene showed a higher serum level of the $1,25(\mathrm{OH})_{2} \mathrm{D}_{3}$ in comparison to the patients carrying the genotypes CC or CG $(\mathrm{p}<0.05)$. There were no differences in the distribution of the other polymorphisms within the CYP24 or CYp27B1 genes and the serum levels of $1,25(\mathrm{OH})_{2} \mathrm{D}_{3}$.

When vitamin $\mathrm{D}$ levels were stratified by the time of year that blood samples were taken, there were no seasonal differences between patients and controls. In addition, there were no correlations between 25(OH)D levels and CD4/CD8 for chemical or clinical characteristics.

\section{Discussion}

The results of this study showed that patients with ACS had significantly lower vitamin D levels in the first few hours after diagnosis compared with a healthy control group. In addition, SNPs in the genes encoding for CYP24 whose mutation have been associated with infantile hypercalcemia ${ }^{41}$ and CYP27B1 were also associated with ACS risk. These polymorphisms might represent a new cardiac risk factor. With our findings it could be postulated that the allele $\mathrm{T}$ is associated with an increased risk for ACS development, while on the other hand the genotype GG within the CYP24 rs2296241 SNP occurred less frequently in ACS patients vs controls (7\% vs 18\%). With genotype AG found more frequently in ACS patients $(79 \%$ vs $57 \%, \mathrm{p}<0.01)$ and the homozygous GG less frequently detected, variant AG was also more frequent in ACS patient. Presumably, the allele G might have a protective effect regarding ACS development, while the allele A may represent increased risk.

Although it is not possible to influence or alter genetic polymorphisms, it may be that vitamin D supplementation could overcome the resulting negative effects. The findings do fit well with what is currently known about the pathophysiology of ACS. Vitamin D deficiency might lead to increased coronary calcification and to plaque rupture. Therefore vascular repair by pro-angiogenic cells after ACS may be attenuated in the presence of vitamin D deficiency.

The finding of an association between CYP24 gene polymorphisms and ACS in this study is in agreement with the results of a previous trial showing that CYP24A1 SNPs were associated with the quantity of coronary artery calcification in three independent populations. ${ }^{42}$
However, the current results contradict those of a large case-control study that failed to find any significant associations between gene polymorphisms within the vitamin D cascade (vitamin D binding protein, CYP2R1, CYP27B1 and CYP24A1) and cardiovascular risk. ${ }^{16}$

Epidemiological evidence exists to support a role for vitamin D metabolites in the development of coronary artery calcification, and the risk of coronary artery disease and ACS. Their results suggested a possible role for vitamin D in the development vascular calcification. ${ }^{23}$ These data suggest that the increased cardiovascular risk associated with vitamin D deficiency might be, at least partly, due to accelerated development of atherosclerosis. Watson et al. measured serum $1,25(\mathrm{OH})_{2} \mathrm{D}_{3}$ in asymptomatic individuals at high risk of coronary heart disease and in those with familial hypercholesterolaemia, but found inverse correlation ${ }^{43}$ between serum $1,25(\mathrm{OH})_{2} \mathrm{D}_{3}$ levels and coronary artery calcification in both groups of patients studied. ${ }^{43}$ Serum levels of $1,25(\mathrm{OH})_{2} \mathrm{D}_{3}$ were also independently and inversely associated with coronary calcium mass in asymptomatic subjects with risk factors for coronary heart disease. ${ }^{24}$ In another study, low 25(OH)D levels were associated with subsequent development of coronary artery calcification. ${ }^{44}$ On the other hand, a number of other studies showed no association between serum vitamin $\mathrm{D}$ levels and coronary calcification. ${ }^{11,38,45-50}$ Such discrepancies in study results with the majority reporting non-beneficial effects mean that the precise role of vitamin D in cardiovascular disease is not yet clear. Nevertheless study design, limit for vitamin D deficiency, age, ethnicity, seasonality among other factors, which may have prevented beneficial vitamin D effects, should be discussed. ${ }^{28,51}$

Vitamin D deficiency is often seen in clinical practice, but it's implications remain to be determined. A number of studies investigating vitamin D supplementation for the primary prevention of cardiovascular disease have had negative outcomes. ${ }^{4,52}$

Important limitations of the current study include its retrospective design and the small number of subjects. However, the results do highlight the important role of vitamin D serum levels and may be also of the vitamin D polymorphisms, at least in the first hours after the diagnosis of ACS. Suggestions for future research include a prospective study comparing vitamin D supplementation and placebo for the primary prevention of cardiovascular disease in individuals who have the 
A

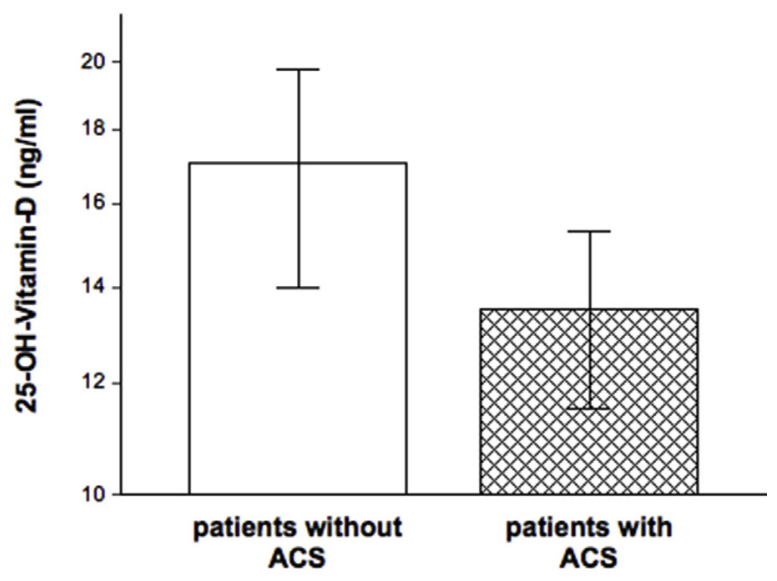

B

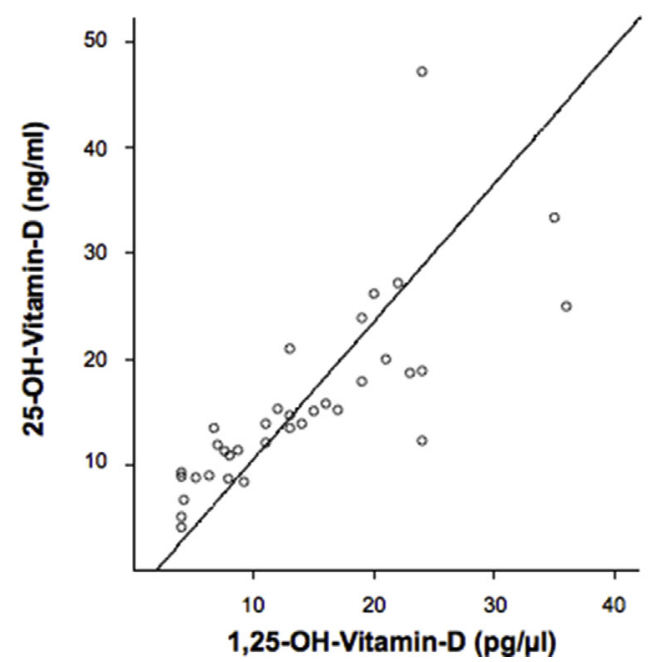

Fig. 1. Distribution of the 25(OH)D levels between patients with ACS and healthy controls.

Fig. 1A shows $25 \mathrm{OH}$ vitamin D levels in $\mathrm{ng} / \mathrm{ml}$ for the 71 patients with ACS and healthy controls (13.2 vs $21.3 \mathrm{ng} / \mathrm{mL}, \mathrm{p}<0.05$ ). Fig. 1B shows the correlation of $1,25 \mathrm{OH}$ vitamin D levels in $\mathrm{pg} / \mu \mathrm{l}$ and $25 \mathrm{OH}$ vitamin D levels in $\mathrm{ng} / \mathrm{ml}$ to demonstrate equilibrium in vitamin D metabolism in the study population.

gene polymorphisms identified in this study as being associated with ACS, and secondary prevention trials examining the effects of vitamin D after MI.

\section{Funding/financial support}

The study was conducted as a non-commercial trial with capital resources of the Department of Cardiology and Department of Endocrinology, Diabetes and Metabolism of the Johann Wolfgang Goethe-University, Frankfurt am Main, Germany.

\section{Declaration of competing interest}

All authors state that there is no conflict of interest in regard to this study.

\section{Acknowledgements}

English language editing assistance was provided by Nicola Ryan, independent medical writer.

Lars Palapies, German Center of Cardiovascular Research (DZHK), Site RheinMain, 60590 Frankfurt am Main, Germany, for help on statistics.

\section{References}

1. Holick MF, Binkley NC, Bischoff-Ferrari HA, et al. Evaluation, treatment, and prevention of vitamin D deficiency: an Endocrine Society clinical practice guideline. $J$ Clin Endocrinol Metab. 2011;96(7):1911-1930.

2. Cheng JB, Levine MA, Bell NH, Mangelsdorf DJ, Russell DW. Genetic evidence that the human CYP2R1 enzyme is a key vitamin D 25-hydroxylase. Proc Natl Acad Sci U S A. 2004;101(20):7711-7715.

3. Zehnder D, Bland R, Walker EA, et al. Expression of 25-hydroxyvitamin D3-1alphahydroxylase in the human kidney. J Am Soc Nephrol. 1999;10(12):2465-2473.

4. Tashiro K, Abe T, Oue N, Yasui W, Ryoji M. Characterization of vitamin D-mediated induction of the CYP 24 transcription. Mol Cell Endocrinol. 2004;226(1-2):27-32.

5. Yang CY, Leung PS, Adamopoulos IE, Gershwin ME. The implication of vitamin D and autoimmunity: a comprehensive review. Clin Rev Allergy Immunol. 2013;45(2):217-226.

6. Levin GP, Robinson-Cohen C, de Boer IH, et al. Genetic variants and associations of 25-hydroxyvitamin D concentrations with major clinical outcomes. JAMA. 2012;308(18):1898-1905.

7. Holick MF. Diabetes and the vitamin d connection. Curr Diabetes Rep. 2008;8(5):393-398.

8. Wang TJ, Pencina MJ, Booth SL, et al. Vitamin D deficiency and risk of cardiovascular disease. Circulation. 2008;117(4):503-511.

9. Castelli WP. Epidemiology of coronary heart disease: the Framingham study. Am $J$ Med. 1984;76(2A):4-12.

10. Anderson JL, May HT, Horne BD, et al. Relation of vitamin D deficiency to cardiovascular risk factors, disease status, and incident events in a general healthcare population. Am J Cardiol. 2010;106(7):963-968.

11. Vimaleswaran KS, Cavadino A, Berry DJ, et al. Association of vitamin D status with arterial blood pressure and hypertension risk: a mendelian randomisation study. Lancet Diabetes Endocrinol. 2014:2(9):719-729.

12. Wang L, Song Y, Manson JE, et al. Circulating 25-hydroxy-vitamin D and risk of cardiovascular disease: a meta-analysis of prospective studies. Circ Cardiovasc Qual Outcomes. 2012;5(6):819-829.

13. Lee JH, Gadi R, Spertus JA, Tang F, O'Keefe JH. Prevalence of vitamin D deficiency in patients with acute myocardial infarction. Am J Cardiol. 2011;107(11):1636-1638.

14. Welles CC, Whooley MA, Karumanchi SA, et al. Vitamin D deficiency and cardiovascular events in patients with coronary heart disease: data from the Heart and Soul Study. Am J Epidemiol. 2014;179(11):1279-1287.

15. Schottker B, Jorde R, Peasey A, et al. Vitamin D and mortality: meta-analysis of individual participant data from a large consortium of cohort studies from Europe and the United States. BMJ. 2014;348:g3656.

16. Kuhn T, Kaaks R, Teucher B, et al. Plasma 25-hydroxyvitamin D and its genetic determinants in relation to incident myocardial infarction and stroke in the European prospective investigation into cancer and nutrition (EPIC)-Germany study. PLoS One. 2013;8(7):e69080.

17. Pilz S, Dobnig H, Nijpels G, et al. Vitamin D and mortality in older men and women. Clin Endocrinol. 2009;71(5):666-672.

18. Giovannucci E, Liu Y, Hollis BW, Rimm EB. 25-hydroxyvitamin D and risk of myocardial infarction in men: a prospective study. Arch Intern Med. 2008;168(11):1174-1180.

19. Dobnig H, Pilz S, Scharnagl H, et al. Independent association of low serum 25-hydroxyvitamin d and 1,25-dihydroxyvitamin d levels with all-cause and cardiovascular mortality. Arch Intern Med. 2008;168(12):1340-1349.

20. Pilz S, Dobnig H, Fischer JE, et al. Low vitamin d levels predict stroke in patients referred to coronary angiography. Stroke. 2008;39(9):2611-2613.

21. Ginde AA, Scragg R, Schwartz RS, Camargo Jr CA. Prospective study of serum 25hydroxyvitamin D level, cardiovascular disease mortality, and all-cause mortality in older U.S. adults. J Am Geriatr Soc. 2009;57(9):1595-1603.

22. Greenland P, LaBree L, Azen SP, Doherty TM, Detrano RC. Coronary artery calcium score combined with Framingham score for risk prediction in asymptomatic individuals. JAMA. 2004:291(2):210-215.

23. Taylor AJ, Bindeman J, Feuerstein I, Cao F, Brazaitis M, O'Malley PG. Coronary calcium independently predicts incident premature coronary heart disease over measured cardiovascular risk factors: mean three-year outcomes in the Prospective Army Coronary Calcium (PACC) project. J Am Coll Cardiol. 2005;46(5):807-814.

24. Doherty TM, Tang W, Dascalos S, et al. Ethnic origin and serum levels of 1alpha,25dihydroxyvitamin D3 are independent predictors of coronary calcium mass measured by electron-beam computed tomography. Circulation. 1997;96(5):1477-1481.

25. Zittermann A, Koerfer R. Vitamin D in the prevention and treatment of coronary heart disease. Curr Opin Clin Nutr Metab Care. 2008;11(6):752-757.

26. Zittermann A, Frisch S, Berthold HK, et al. Vitamin D supplementation enhances the beneficial effects of weight loss on cardiovascular disease risk markers. Am J Clin Nutr. 2009;89(5):1321-1327.

27. Chen S, Law CS, Grigsby CL, et al. Cardiomyocyte-specific deletion of the vitamin D receptor gene results in cardiac hypertrophy. Circulation. 2011;124(17):1838-1847.

28. Zittermann A. Vitamin D and cardiovascular disease. Anticancer Res. 2014;34(9):4641-4648.

29. Elamin MB, Abu Elnour NO, Elamin KB, et al. Vitamin D and cardiovascular outcomes: a systematic review and meta-analysis. J Clin Endocrinol Metab. 
2011;96(7):1931-1942.

30. Beveridge LA, Struthers AD, Khan F, et al. Effect of vitamin D supplementation on blood pressure: a systematic review and meta-analysis incorporating individual patient data. JAMA Intern Med. 2015;175(5):745-754.

31. Thygesen K, Alpert JS, Jaffe AS, et al. Third universal definition of myocardial infarction. Eur Heart J. 2012;33(20):2551-2567.

32. Miller SA, Dykes DD, Polesky HF. A simple salting out procedure for extracting DNA from human nucleated cells. Nucleic Acids Res. 1988;16(3):1215.

33. Ramos-Lopez E, Bruck P, Jansen T, Herwig J, Badenhoop K. CYP2R1 (vitamin D 25hydroxylase) gene is associated with susceptibility to type 1 diabetes and vitamin D levels in Germans. Diabetes Metab Res Rev. 2007;23(8):631-636.

34. Bailey R, Cooper JD, Zeitels L, et al. Association of the vitamin D metabolism gene CYP27B1 with type 1 diabetes. Diabetes. 2007;56(10):2616-2621.

35. Penna-Martinez M, Ramos-Lopez E, Stern J, et al. Impaired vitamin D activation and association with CYP24A1 haplotypes in differentiated thyroid carcinoma. Thyroid. 2012;22(7):709-716

36. Pani MA, Regulla K, Segni M, et al. A polymorphism within the vitamin D-binding protein gene is associated with Graves' disease but not with Hashimoto's thyroiditis. $J$ Clin Endocrinol Metab. 2002;87(6):2564-2567.

37. Kurylowicz A, Ramos-Lopez E, Bednarczuk T, Badenhoop K. Vitamin D-binding protein (DBP) gene polymorphism is associated with Graves' disease and the vitamin D status in a Polish population study. Exp Clin Endocrinol Diabetes. 2006;114(6):329-335

38. Malabanan A, Veronikis IE, Holick MF. Redefining vitamin D insufficiency. Lancet. 1998;351(9105):805-806.

39. Imbens $\mathrm{G}$. The role of the propensity score in estimating dose-response functions. Biometrika. 2000;87:706-710.

40. Imbens GW. Nonparametric estimation of average treatment effects under exogeneity: a review. Rev Econ Stat. 2004;86(1):4-29.

41. Schlingmann KP, Kaufmann M, Weber S, et al. Mutations in CYP24A1 and idiopathic infantile hypercalcemia. $N$ Engl J Med. 2011;365(5):410-421.

42. Shen H, Bielak LF, Ferguson JF, et al. Association of the vitamin D metabolism gene
CYP24A1 with coronary artery calcification. Arterioscler Thromb Vasc Biol. 2010;30(12):2648-2654.

43. Watson KE, Abrolat ML, Malone LL, et al. Active serum vitamin D levels are inversely correlated with coronary calcification. Circulation. 1997;96(6):1755-1760.

44. de Boer IH, Kestenbaum B, Shoben AB, Michos ED, Sarnak MJ, Siscovick DS. 25hydroxyvitamin D levels inversely associate with risk for developing coronary artery calcification. J Am Soc Nephrol. 2009;20(8):1805-1812.

45. Arad Y, Spadaro LA, Roth M, et al. Serum concentration of calcium, 1,25 vitamin D and parathyroid hormone are not correlated with coronary calcifications. An electron beam computed tomography study. Coron Artery Dis. 1998;9(8):513-518.

46. Bajaj A, Stone KL, Peters K, et al. Circulating vitamin D, supplement use, and cardiovascular disease risk: the MrOS Sleep Study. J Clin Endocrinol Metab. 2014;99(9):3256-3262.

47. Michos ED, Streeten EA, Ryan KA, et al. Serum 25-hydroxyvitamin d levels are not associated with subclinical vascular disease or C-reactive protein in the old order amish. Calcif Tissue Int. 2009;84(3):195-202.

48. Sollid ST, Hutchinson MY, Fuskevag OM, et al. No effect of high-dose vitamin D supplementation on glycemic status or cardiovascular risk factors in subjects with prediabetes. Diabetes Care. 2014;37(8):2123-2131.

49. Verdoia M, Schaffer A, Sartori C, et al. Vitamin D deficiency is independently associated with the extent of coronary artery disease. Eur J Clin Invest. 2014;44(7):634-642.

50. Vimaleswaran KS, Power C, Hypponen E. Interaction between vitamin D receptor gene polymorphisms and 25-hydroxyvitamin D concentrations on metabolic and cardiovascular disease outcomes. Diabetes Metab. 2014;40(5):386-389.

51. Chowdhury R, Kunutsor S, Vitezova A, et al. Vitamin D and risk of cause specific death: systematic review and meta-analysis of observational cohort and randomised intervention studies. BMJ. 2014;348:g1903.

52. Witham MD, Adams F, Kabir G, Kennedy G, Belch JJ, Khan F. Effect of short-term vitamin D supplementation on markers of vascular health in South Asian women living in the UK-a randomised controlled trial. Atherosclerosis. 2013;230(2):293-299. 